\title{
Copper complexes as chemical nucleases
}

\author{
AKHIL R CHAKRAVARTY*, PATTUBALA A N REDDY, \\ BIDYUT K SANTRA and ANITHA M THOMAS \\ Department of Inorganic and Physical Chemistry, Indian Institute of Science, \\ Bangalore 560 012, India \\ e-mail: arc@ipc.iisc.ernet.in
}

\begin{abstract}
Redox active mononuclear and binuclear copper(II) complexes have been prepared and structurally characterized. The complexes have planar N-donor heterocyclic bases like 1,10-phenanthroline (phen), dipyridoquinoxaline (dpq) and dipyridophenazine (dppz) ligands that are suitable for intercalation to B-DNA. Complexes studied for nuclease activity have the formulations $\left[\mathrm{Cu}(\mathrm{dpq})_{2}\left(\mathrm{H}_{2} \mathrm{O}\right)\right]$ $\left(\mathrm{ClO}_{4}\right)_{2} \cdot \mathrm{H}_{2} \mathrm{O}(\mathbf{1}),\left[\left\{\mathrm{CuL}\left(\mathrm{H}_{2} \mathrm{O}\right)\right\}_{2}(\mu-\mathrm{ox})\right]\left(\mathrm{ClO}_{4}\right)_{2}(\mathrm{~L}=$ bpy, 2 ; phen, 3; dpq, 4; and dppz, 5) and $[\mathrm{Cu}(\mathrm{L})($ salgly $)](\mathrm{L}=\mathrm{bpy}, \mathbf{6}$; phen, 7; dpq, 8; and dppz, 9), where salgly is a tridentate Schiff base obtained from the condensation of glycine and salicylaldehyde. The dpq complexes are efficient DNA binding and cleavage active species. The dppz complexes show good binding ability but poor nuclease activity. The cleavage activity of the bis-dpq complex is significantly higher than the bis-phen complex of copper(II). The nuclease activity is found to be dependent on the intercalating nature of the complex and on the redox potential of the copper(II)/copper(I) couple. The ancillary ligand plays a significant role in binding and cleavage activity.
\end{abstract}

Keywords. Copper(II) complexes; nuclease activity; catalytic properties; DNA binding.

\section{Introduction}

Chemical nucleases are redox active coordination complexes that cleave DNA by an oxidative pathway. Direct scission of DNA by oxidizing or hydrolytic agents is the subject matter for several current review articles ${ }^{1-10}$. Redox-active transition metal complexes in the presence of oxidants have been extensively used for DNA cleavage reactions. In a typical reaction, an oxidising agent like $\mathrm{O}_{2}, \mathrm{H}_{2} \mathrm{O}_{2}$ or a peracid is added in addition to the transition metal complex. There are also examples where chemically or electrochemically generated metal in high oxidation state can act as an oxidant in the presence of a reductant. Generally, metal complexes capable of abstracting a ribosyl hydrogen are as well expected to oxidize guanine or other nucleobases. Current efforts are on to design transition metal complexes as chemical nucleases suitable for plasmid nicking or in a direct strand scission.

Among the transition metal based cleaving reagents, the chemistry of copper, particularly copper phenanthroline complexes, is primarily sugar directed. Copper complexes usually do not mediate nucleobase oxidation, but are responsible for direct strand scission by hydrogen atom abstraction from the deoxyribose moiety. Sigman and coworkers have shown that bis-(1,10-phenanthroline)copper(I) complex in presence of

*For correspondence 
$\mathrm{H}_{2} \mathrm{O}_{2}$ efficiently cleaves DNA ${ }^{1,2}$. The importance in DNA binding and cleavage by redox and photoactive metal complexes is primarily for examining the sequence specificities of DNA binding using a variety of intercalating ligands by 'footprinting' methods ${ }^{1,2,11-15}$. Although the true binding mode of the bis-phen complex to DNA is presently unknown, it has been suggested that the nuclease activity of $\left[\mathrm{Cu}(\text { phen })_{2}\right]^{+}$is related to the partial intercalation or binding of one phen ligand to the minor groove of DNA while the other phen ligand makes favourable contact within the groove.

The key intermediate in nucleic acid oxidation is the formation of an active $\mathrm{Cu}(\mathrm{III})-\mathrm{OH}$ species leading to the generation of freely diffusible $\mathrm{HO}$ - which abstracts proton from the deoxyribose $\mathrm{C}-4^{\prime}$ or $\mathrm{C}-1^{\prime}$ position. The formation of $\mathrm{Cu}(\mathrm{I}) \mathrm{OOH}$ or $\mathrm{Cu}(\mathrm{III})-\mathrm{OH}$ has earlier been proposed for the nucleobase oxidation involving $\mathrm{CuCl}_{2}$ in presence of $\mathrm{H}_{2} \mathrm{O}_{2}$ or $\mathrm{O}_{2}$ with a reductant like ascorbate, reduced glutathione or NADH in DNA strand breaking giving the order $\mathrm{T}>\mathrm{G}>\mathrm{C}>\mathrm{A}^{16,17}$. The $1: 1$ complex formed by $\mathrm{CuCl}_{2}$ with the anticancer drug famotidine has been shown as a better catalyst than $\mathrm{CuCl}_{2}$ for sulfite autooxidation leading to DNA damage ${ }^{18,19}$. Similarly $\mathrm{Cu}^{2+}$ ion and $\mathrm{H}_{2} \mathrm{O}_{2}$ in the presence of L-dopa or a catechol, greatly enhance DNA oxidation ${ }^{20}$.

The nuclease activity of $\left[\mathrm{Cu}(\text { phen })_{2}\right]^{+}$was discovered by Sigman and coworkers in 1979 while they were investigating the inhibition of the poly $[\mathrm{d}(A-T)]$ directed polymerization catalysed by $E$. coli DNA polymerase I in presence of phen ligand ${ }^{21}$. They have observed that DNA strand scission requires the mole ratio of 2:1 for the 1,10 phenanthroline and copper in this complex. The role of phen ligand is to modulate the redox potential of the $\mathrm{Cu}(\mathrm{II}) / \mathrm{Cu}(\mathrm{I})$ couple and to bind DNA leading to the occurence of the oxidative chemistry of the cuprous complex at the surface of the nucleic acid ${ }^{1,2}$. The novel nuclease activity of the bis(phen)copper complex has prompted us to synthesize redox active copper complexes having planar $\mathrm{N}$-donor heterocyclic ligands suitable for nuclease activity studies. Herein we report the binding and nuclease activities of three types of copper(II) complexes, viz. $\left[\mathrm{Cu}(\mathrm{dpq})_{2}\left(\mathrm{H}_{2} \mathrm{O}\right)\right]\left(\mathrm{ClO}_{4}\right)_{2} \cdot \mathrm{H}_{2} \mathrm{O}(\mathbf{1}),\left[\left\{\mathrm{Cu}(\mathrm{L})\left(\mathrm{H}_{2} \mathrm{O}\right)\right\}_{2}\right.$ ( tridentate Schiff-base derived from salicylaldehyde and glycine; $\mathrm{L}=\mathrm{bpy}$, 6; phen, 7; dpq, 8; dppz, 9), where $d p q$ and $d p p z$ are dipyridoquinoxaline and dipyridophenazine, respectively.

\section{Results and discussion}

\subsection{DNA binding and nuclease activity of $\left[\mathrm{Cu}(\mathrm{dpq})_{2}\left(\mathrm{H}_{2} \mathrm{O}\right)\right]\left(\mathrm{ClO}_{4}\right)_{2} \cdot \mathrm{H}_{2} \mathrm{O}(\mathbf{1})$}

Dipyridoquinoxaline (dpq) ligand with an extended planar quinoxaline moiety is expected to be a better binder to DNA compared to 1,10-phen and other substituted phen ligands. The dpq complex is likely to show enhanced nuclease activity than its phen analogue. This part of the work stems from our interest to explore the DNA binding and nuclease activity of the bis-dpq complex of copper(II) ${ }^{22}$.

Complex 1 was prepared from a reaction of copper(II) perchlorate with dipyridoquinoxaline in methanol. The complex was structurally characterized. A perspective view of the molecule is shown in figure 1. The complex has a $\mathrm{CuN}_{4} \mathrm{O}$ coordination geometry with a distorted trigonal bipyramidal structure. It exhibits a visible spectral $d-d$ band at $718 \mathrm{~nm}$ in $\mathrm{MeCN}$. The complex is redox active and displays a $\mathrm{Cu}(\mathrm{II}) / \mathrm{Cu}(\mathrm{I})$ couple at $0.09 \mathrm{~V}$ with a $\Delta E_{p}$ value of $229 \mathrm{mV}$ at a scan rate of $50 \mathrm{mV} \mathrm{s}{ }^{-1}$. The complex undergoes facile reduction with sodium ascorbate in an aqueous-DMF 


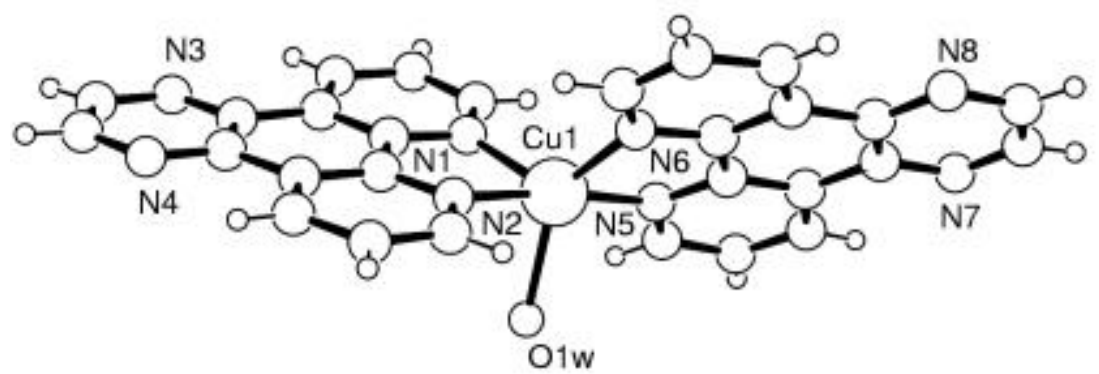

Figure 1. A perspective view of the cationic complex $\left[\mathrm{Cu}(\mathrm{dpq})_{2}\left(\mathrm{H}_{2} \mathrm{O}\right)\right]^{2+}$.

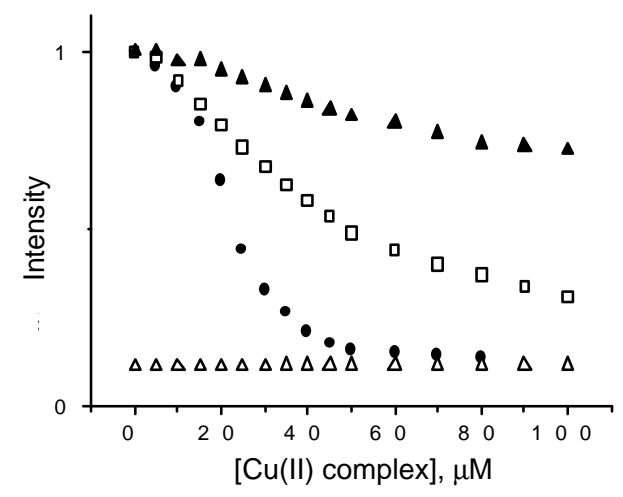

Figure 2. Effect of addition of bis-chelate copper(II) complexes (dpq, $\bullet$; phen, $\square$; bpy, $\boldsymbol{\Delta})$ to the emission intensity of the CT DNA-bound ethidium bromide at different complex concentrations. The emission intensity of EB in absence of DNA is also shown $(\Delta)$.

medium $(4: 1 v / v)$ to form an unstable brown copper(I) species which readily converts to $\mathbf{1}$ on exposure to air.

The binding of complex 1 with calf thymus DNA has been studied by fluorescence spectral method. Competitive binding studies have been made using ethidium bromide (EB) intercalator which showed enhanced emission intensity compared to free $\mathrm{EB}^{23,24}$. Intercalation of the complex to the DNA displaces bound EB and the emission intensity reduces due to fluorescence quenching of the free $\mathrm{EB}$ molecules by water ${ }^{25,26}$. Figure 2 shows the decrease of the emission intensity of the EB on addition of complex $\mathbf{1}$. A comparison of the data can be made with the binding studies done using analogous bpy and phen complexes. The bpy species shows no apparent intercalation. Complex 1 with a greater slope has significantly higher binding affinity than its phen analogue.

DNA cleavage studies have been made by gel electrophoresis using supercoiled

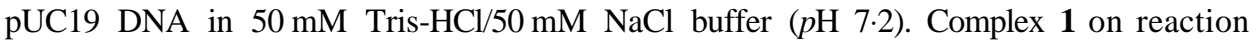
with the DNA in presence of ascorbic acid $\left(\mathrm{H}_{2} \mathrm{~A}\right)$ shows nuclease activity which is better than its phen analogue (figure 3 ). The bpy complex, $\left[\mathrm{Cu}(\mathrm{bpy})_{2}\right]^{2+}$ does not show any apparent cleavage. At a concentration of $15 \mu \mathrm{M}$, the dpq complex is able to convert $75 \%$ 


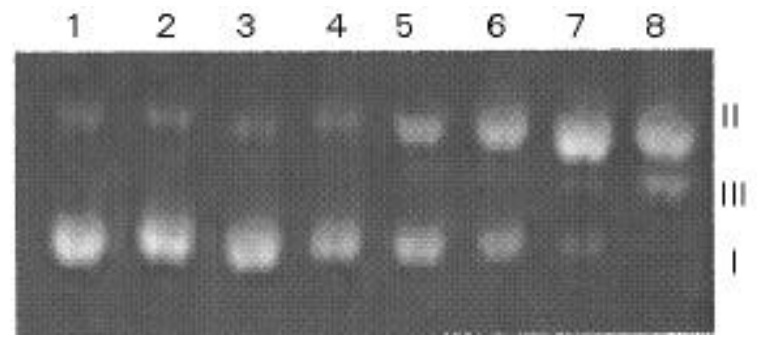

Figure 3. Cleavage of SC pUC19 DNA $(0 \cdot 5 \mu \mathrm{g})$ by copper complexes in presence of ascorbic acid $\left(\mathrm{H}_{2} \mathrm{~A}, 100 \mu \mathrm{M}\right)$ in a $50 \mathrm{mM}$ Tris- $\mathrm{HCl}+50 \mathrm{mM} \mathrm{NaCl}$ buffer at $37^{\circ} \mathrm{C}$. Lane 1, DNA control; lane 2, DNA + complex 1; lane 3, DNA $+\mathrm{H}_{2} \mathrm{~A}$; lane 4, $\mathrm{DNA}+$ bis-bpy $\mathrm{Cu}(\mathrm{II})$ complex $+\mathrm{H}_{2} \mathrm{~A}$; lanes 5 and 6 , DNA + bis-phen $\mathrm{Cu}(\mathrm{II})$ complex $+\mathrm{H}_{2} \mathrm{~A}$; lanes 7 and 8, DNA $+1+\mathrm{H}_{2} \mathrm{~A}$ [complex concentrations: $15 \mu \mathrm{M}$ for lanes 5 and $7 ; 30 \mu \mathrm{M}$ for lanes 2, 4, 6 and 8].

of the initial supercoiled (SC) to nicked circular (NC) form whereas the phen analogue can convert only $17 \%$ of the SC. At a higher concentration of $30 \mu \mathrm{M}$, the dpq complex shows complete cleavage while the phen analogue displays only $40 \%$ conversion.

\subsection{DNA binding and nuclease activity of $\left[\left\{\mathrm{Cu}(\mathrm{L})\left(\mathrm{H}_{2} \mathrm{O}\right)\right\}_{2}(\boldsymbol{\mu} \mathrm{tox})\right]\left(\mathrm{ClO}_{4}\right)_{2}(\mathbf{2}-\mathbf{5})$}

Rill and coworkers have earlier shown that a mole ratio of 2:1 for the phen and copper is needed for observing efficient nuclease activity, regardless of the reducing agent used in the cleavage reaction ${ }^{27}$. This part of the work stems from our interest to study the DNA binding and cleavage properties of dicopper(II) complexes by covalently linking two mono-phen copper and related units by a planar oxalate bridge to form a dinuclear species having a ligand to copper mole ratio as $1: 1^{26}$. We have prepared four such complexes of general formulation $\left[\left\{\mathrm{Cu}(\mathrm{L})\left(\mathrm{H}_{2} \mathrm{O}\right)\right\}_{2}(\mu\right.$ tox $\left.)\right]\left(\mathrm{ClO}_{4}\right)_{2}$ ( $\mathrm{L}=$ bpy, 2; phen, 3; dpq, 4; dppz, 5) from a reaction of $\mathrm{Cu}\left(\mathrm{ClO}_{4}\right)_{2} \cdot 6 \mathrm{H}_{2} \mathrm{O}$ with the bidentate $\mathrm{N}$-donor heterocyclic base (L) and sodium oxalate in aquous ethanol. The complexes display characteristic infrared bands in the ranges 1651-1662 and $1077-1098 \mathrm{~cm}^{-1}$ for the oxalate and perchlorate, respectively. The complexes show a $d-d$ band in the range 650$720 \mathrm{~nm}$ in aqueous DMF solution. Complexes $\mathbf{1}$ and $\mathbf{3}$ have been structurally characterised. A perspective view of complex $\mathbf{3}$ is shown in figure 4. The structure consists of a centrosymmetric complex in which the $\mathrm{Cu}(\mathrm{dpq})\left(\mathrm{H}_{2} \mathrm{O}\right)$ units are bridged by an oxalate. The separation between two copper centres is 5.138(2) $\AA$. In the squarepyramidal geometry, the deviation of copper from the basal plane is $0.062 \AA$. The angle formed between two basal planes is $2 \cdot 6^{\circ}$.

The complexes are redox active and show two cyclic voltammetric responses in the potential range 0.07 to $-0.31 \mathrm{~V}$ vs SCE in a dmf-50 mM Tris-HCl/ $0.1 \mathrm{M} \mathrm{KCl}$ buffer $(1: 1$ $v / v, p \mathrm{H}$ 7.2). They are assignable to the $\mathrm{Cu}_{2}(\mathrm{II}) / \mathrm{Cu}(\mathrm{II}) \mathrm{Cu}(\mathrm{I})$ and $\mathrm{Cu}(\mathrm{II}) \mathrm{Cu}(\mathrm{I}) / \mathrm{Cu}_{2}(\mathrm{I})$ couples. A $\Delta E_{p}$ value in the range $100-250 \mathrm{mV}$ at $50 \mathrm{mV} \mathrm{s}^{-1}$ with the ratio of the cathodic to anodic peak currents as unity suggests the quasireversible nature of the electron transfer process. The $E_{1 / 2}$ values for the $\mathrm{Cu}_{2}(\mathrm{II}) / \mathrm{Cu}(\mathrm{II}) \mathrm{Cu}(\mathrm{I})$ couple are $-0 \cdot 05,-0 \cdot 04,0.02$ and $0.07 \mathrm{~V}$ for the complexes $\mathbf{2}-\mathbf{5}$ respectively. The $E_{1 / 2}$ values for the $\mathrm{Cu}(\mathrm{II}) \mathrm{Cu}(\mathrm{I}) / \mathrm{Cu}_{2}(\mathrm{I})$ couple are $-0.31,-0.27,-0.22$ and $-0.20 \mathrm{~V}$, respectively, for $2-5$. The complexes 


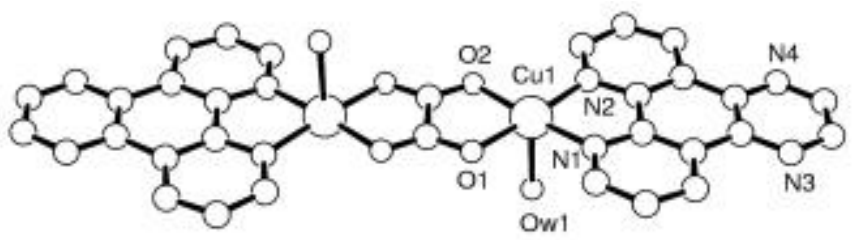

Figure 4. A perspective view of the cationic complex in $\left[\mathrm{Cu}_{2}(\mathrm{ox})(\mathrm{dpq})_{2}\right.$ $\left.\left(\mathrm{H}_{2} \mathrm{O}\right)_{2}\right]\left(\mathrm{ClO}_{4}\right)_{2} \cdot 2 \mathrm{H}_{2} \mathrm{O}$.

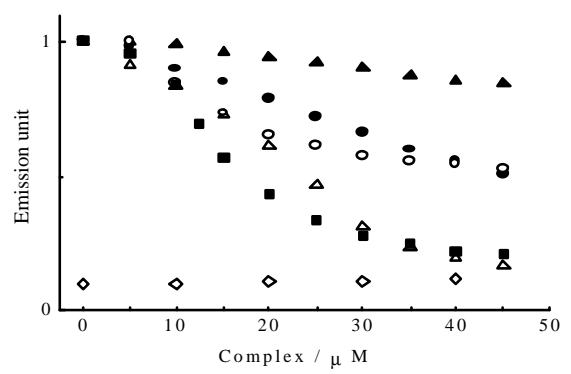

Figure 5. The emission intensity of CT DNA-bound ethidium bromide $(12.5 \mu \mathrm{M})$ at different complex concentrations for the complexes $\left[\left\{\mathrm{LCu}\left(\mathrm{H}_{2} \mathrm{O}\right)\right\}_{2}(\mu\right.$-ox $\left.)\right]\left(\mathrm{ClO}_{4}\right)_{2}$ ( $\mathrm{L}=$ bpy, $\mathbf{\Delta}$; phen, $\square$; dpq, $\mathbf{\square}$; dppz, $\Delta$ ) and the bis-phen copper(II) species $(\bullet)$. The emission intensity of EB in absence of DNA in $5 \mathrm{mM}$ Tris- $\mathrm{HCl}+50 \mathrm{mM} \mathrm{NaCl}$ buffer $\left(p \mathrm{H} \mathrm{7.2)} \mathrm{containing} 3 \% \mathrm{dmf}\right.$ at $25^{\circ} \mathrm{C}$ is also shown $(\diamond)$.

undergo facile reduction with ascorbic acid to form an unstable brown $\mathrm{Cu}(\mathrm{I})$ species which converts to the copper(II) complex on exposure to dioxygen. The catalytic process is effective with a mole ratio of the ascorbic acid to the complex as $\sim 100$ for complexes 2 and $\mathbf{3}$ and $\sim 60$ for complexes $\mathbf{4}$ and $\mathbf{5}$.

The binding ability of the complexes $\mathbf{2}-\mathbf{5}$ to the calf thymus DNA has been studied by fluorescence spectral method. The decrease in the emission intensity of the EB on addition of the dimeric complexes and the mononuclear bis-phen copper(II) complex is shown in figure 5. The bpy complex showing a near zero slope is essentially unable to dislocate the DNA-bound EB molecules due to lack of any intercalation ability of the bpy ligand. The dpq and dppz complexes showing higher slopes than the bis-phen copper(II) species indicate significant binding ability which follows the order: 4>5>3> $\mathrm{Cu}$ (phen $)_{2}{ }^{2+} \square \mathbf{2}$.

The complexes are nuclease active. The cleavage activity of the complexes has been determined from gel electrophoresis based on their ability to convert supercoiled (SC) pUC19 DNA to nicked circular (NC) DNA form (figure 6, table 1). There are several interesting findings in this study. The complexes 2-5 have a $\mathrm{Cu}$ : heterocyclic base ratio as 1:1. The bpy complex has been found to be nuclease inactive and a poor binder to DNA. This clearly suggests that the DNA binding in the form of intercalation could be an important factor for the cleavage activity. The luminescence experiments monitoring the emission of DNA bound EB strongly suggest the intercalative mode of binding. 

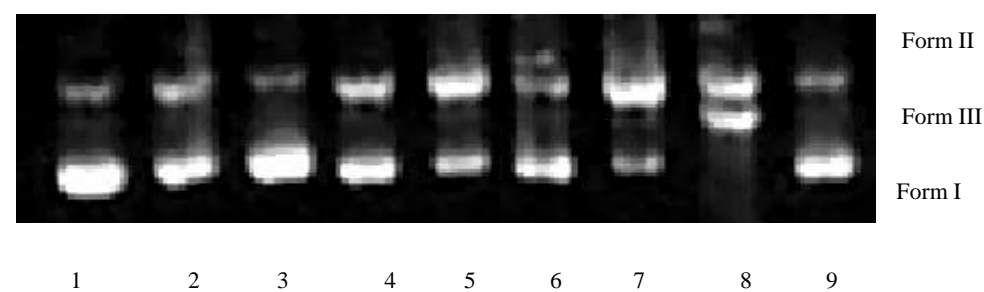

Figure 6. Cleavage of SC pUC19 DNA $(0.5 \mu \mathrm{g})$ by the binuclear complexes $(30 \mu \mathrm{M})$ in presence of ascorbic acid $\left(\mathrm{H}_{2} \mathrm{~A}\right)$. Lane 1, DNA control; lane 2, DNA + $\mathrm{H}_{2} \mathrm{~A}$; lane 3, DNA + complex 4; lane 4, DNA + $\mathrm{H}_{2} \mathrm{~A}+$ mono-phen $\mathrm{Cu}$ (II) species; lane 5, DNA + $\mathrm{H}_{2} \mathrm{~A}+$ bis-phen $\mathrm{Cu}$ (II) species; lanes 6-9, DNA + $\mathrm{H}_{2} \mathrm{~A}+$ complexes $\mathbf{2}-\mathbf{5}$, respectively.

Table 1. DNA (pUC19) cleavage data of the complexes 2-5 along with the mono and bis-phen complexes of copper(II).

\begin{tabular}{|c|c|c|c|c|}
\hline \multirow{2}{*}{$\begin{array}{l}\text { Sl. } \\
\text { no. }^{\text {a }}\end{array}$} & \multirow[b]{2}{*}{ Reaction condition ${ }^{\mathrm{b}}$} & \multicolumn{3}{|c|}{ Form $(\%)$} \\
\hline & & SC & $\mathrm{NC}$ & Linear \\
\hline 1 & DNA control & 90 & 10 & \\
\hline 2 & DNA + ascorbic acid $\left(\mathrm{H}_{2} \mathrm{~A}\right)$ & 83 & 17 & \\
\hline 3 & $\mathrm{DNA}+\left[\mathrm{Cu}_{2}(\mathrm{dpq})_{2}\left(\mathrm{H}_{2} \mathrm{O}\right)_{2}(\mathrm{ox})\right]\left(\mathrm{ClO}_{4}\right)_{2}(\mathbf{4})$ & 90 & 10 & \\
\hline 4 & $\mathrm{DNA}+\mathrm{H}_{2} \mathrm{~A}+\left[\mathrm{Cu}(\right.$ phen $\left.)\left(\mathrm{H}_{2} \mathrm{O}\right)_{2}\right]\left(\mathrm{ClO}_{4}\right)_{2}$ & 70 & 30 & \\
\hline 5 & $\mathrm{DNA}+\mathrm{H}_{2} \mathrm{~A}+\left[\mathrm{Cu}(\text { phen })_{2}\left(\mathrm{H}_{2} \mathrm{O}\right)\right]\left(\mathrm{ClO}_{4}\right)_{2}$ & 40 & 60 & \\
\hline 6 & $\mathrm{DNA}+\mathrm{H}_{2} \mathrm{~A}+\left[\mathrm{Cu}_{2}(\mathrm{bpy})_{2}\left(\mathrm{H}_{2} \mathrm{O}\right)_{2}(\mathrm{ox})\right]\left(\mathrm{ClO}_{4}\right)_{2}(2)$ & 80 & 20 & \\
\hline 7 & $\mathrm{DNA}+\mathrm{H}_{2} \mathrm{~A}+\left[\mathrm{Cu}_{2}(\text { phen })_{2}\left(\mathrm{H}_{2} \mathrm{O}\right)_{2}(\mathrm{ox})\right]\left(\mathrm{ClO}_{4}\right)_{2}(\mathbf{3})$ & 28 & 72 & \\
\hline 8 & $\mathrm{DNA}+\mathrm{H}_{2} \mathrm{~A}+\left[\mathrm{Cu}_{2}(\mathrm{dpq})_{2}\left(\mathrm{H}_{2} \mathrm{O}\right)_{2}(\mathrm{ox})\right]\left(\mathrm{ClO}_{4}\right)_{2}(\mathbf{4})$ & 0 & 55 & 45 \\
\hline 9 & $\mathrm{DNA}+\mathrm{H}_{2} \mathrm{~A}+\left[\mathrm{Cu}_{2}(\mathrm{dppz})_{2}\left(\mathrm{H}_{2} \mathrm{O}\right)_{2}(\mathrm{ox})\right]\left(\mathrm{ClO}_{4}\right)_{2}(\mathbf{5})$ & 78 & 22 & \\
\hline
\end{tabular}

${ }^{\mathrm{a}}$ The serial numbers correspond to the lanes shown in figure $6 .{ }^{\mathrm{b}}$ Concentrations of different species: $\mathrm{H}_{2} \mathrm{~A} 100 \mu \mathrm{M}$; copper complexes $30 \mu \mathrm{M}$; DNA $\approx 500 \mathrm{ng}$. Reaction

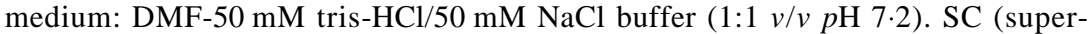
coiled), NC (nicked circular) and linear are different forms of DNA

Complexes 3-5 are avid binders to DNA. The significant binding observed for the dpq and dppz complexes could be related to the presence of extended aromatic ring making intercalation more favourable between the $\pi$-system of the ligand and the DNA base pairs. The dpq and dppz complexes, however, drastically differ in their cleavage activities in presence of a reducing agent like ascorbic acid. The anomalous activity of $\mathbf{5}$ could be related to the enhancement of the stability of the cuprous complex in presence of hydrophobic interactions with the DNA. A stable copper(I) complex is unlikely to react with dioxygen to form the reactive copper-oxo species. The other possibility is the difference in the groove selectivity of the dpq and dppz ligands. Control experiments done by the research group of Collins and Barton have shown that while phen and dpq ligands prefer to intercalate through the minor groove ${ }^{28-30}$, complexes containing dppz bind to DNA through the major groove ${ }^{31-33}$. The mechanistic pathways for DNA cleavage involving the minor and major grooves are known to yield different scission products ${ }^{1-8}$. It is likely that the dpq complex intercalates through the minor groove, while the dppz complex $\mathbf{5}$ may prefer the major groove for binding. 
Catalytic studies done on the complexes 2-5 in a buffer medium in presence of ascorbic acid show that a cleavage of the dimeric unit to two monomeric species takes place as $\left[\left\{\mathrm{Cu}^{\mathrm{II}} \mathrm{L}\left(\mathrm{H}_{2} \mathrm{O}\right)\right\}_{2}(\mu\right.$ tox $\left.)\right]\left(\mathrm{ClO}_{4}\right)_{2}+\mathrm{H}_{2} \mathrm{~A} \rightarrow 2\left[\mathrm{LCu}^{\mathrm{I}}\left(\mathrm{H}_{2} \mathrm{O}\right)\left(\mathrm{ClO}_{4}\right)\right]+\mathrm{A}+\mathrm{H}_{2} \mathrm{C}_{2} \mathrm{O}_{4}$. Such a monomeric complex containing the dppz ligand is likely to be stable in the cuprous form due to hydrophobic interactions of the extended aromatic rings of dppz with the DNA helix. This could be a possibility for the nuclease inactivity of the complex.

\subsection{DNA binding and nuclease activity of $[\mathrm{Cu}($ salgly $)(\mathrm{L})] .4 \mathrm{H}_{2} \mathrm{O}(\mathbf{6}-\mathbf{9})$}

In order to understand the influence of ancillary ligand on the DNA binding and cleavage activity, we have prepared a series of mixed ligand copper(II) complexes containing a tridentate ONO-donor Schiff base ligand (salgly), obtained from the condensation of salicylaldehyde with glycine. The complexes of formulation $[\mathrm{Cu}(\mathrm{salgly})(\mathrm{L})](6-9)$ where $\mathrm{L}=$ bpy (6), phen (7), dpq (8) and dppz (9) have been prepared by reacting $\left[\mathrm{Cu}(\right.$ salgly $\left.)\left(\mathrm{H}_{2} \mathrm{O}\right)\right]$ with $\mathrm{L}$ in aqueous methanol. The complexes were characterized from elemental analytical and spectral data. The complexes display a $d-d$ band in the range $650-700 \mathrm{~nm}$ in methanol. Complex 6 with four waters of crystallization has been structurally characterized and a perspective view of the complex is shown in figure 7 . The complexes have a distorted square-pyramidal (4+1) structure with a $\mathrm{N}_{2} \mathrm{O}_{2}$ basal plane. The heterocyclic ligand occupies the axial-equatorial sites of the square-pyramidal structure. The water molecules show chemically significant intra and intermolecular hydrogen bonding interactions.

The DNA binding studies of the complexes 6-9 have been made by fluorescence spectral method by monitoring the decrease in the emission intensity of the ethidium bromide molecules bound to DNA on addition of the metal complex. Figure 8 shows the variation of the binding ability of different complexes. While [Cu(salgly)(dpq)] (8) shows similar binding ability as $\left[\mathrm{Cu}(\mathrm{phen})_{2}\right]^{2+}$, the bpy complex 6 is a poor binder to CT DNA. The complexes $[\mathrm{Cu}($ salgly)(phen)] (7) and $[\mathrm{Cu}($ salgly)(dppz)] (9) show similar binding ability. It is interesting that dppz ligand with an extended $\pi$-aromatic ring is less

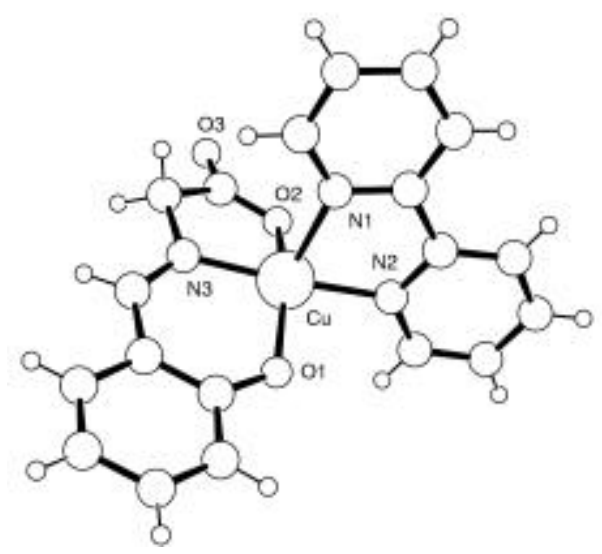

Figure 7. A perspective view of $[\mathrm{Cu}($ salgly $)($ bpy) $)(6)$. 


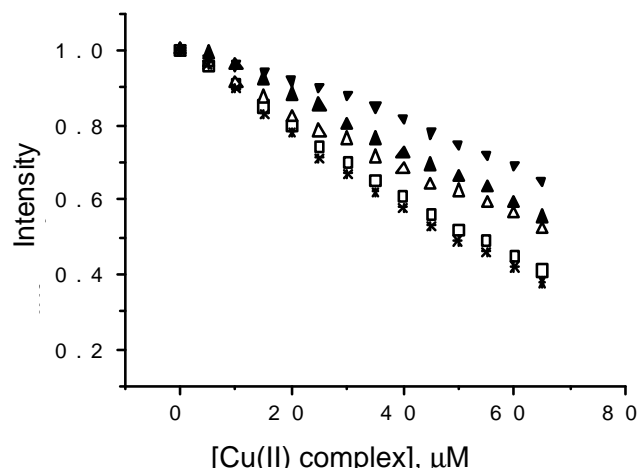

Figure 8. Effect of addition of copper(II) complexes of formulation [Cu(salgly)(L)] $(\mathrm{L}=$ bpy, $\boldsymbol{\nabla}$; phen, $\Delta$; dpq, and dppz, $\mathbf{\Delta})$ along with $\left[\mathrm{Cu}(\mathrm{phen})_{2}\right]^{2+}(*)$ to the emission intensity of CT DNA-bound ethidium bromide $(12.5 \mu \mathrm{M})$ in 5 mMTris$\mathrm{HCl}+50 \mathrm{mM} \mathrm{NaCl}$ buffer $\left(p \mathrm{H} \mathrm{7.2)}\right.$ containing $1 \% \mathrm{DMF}$ at $25^{\circ} \mathrm{C}$.

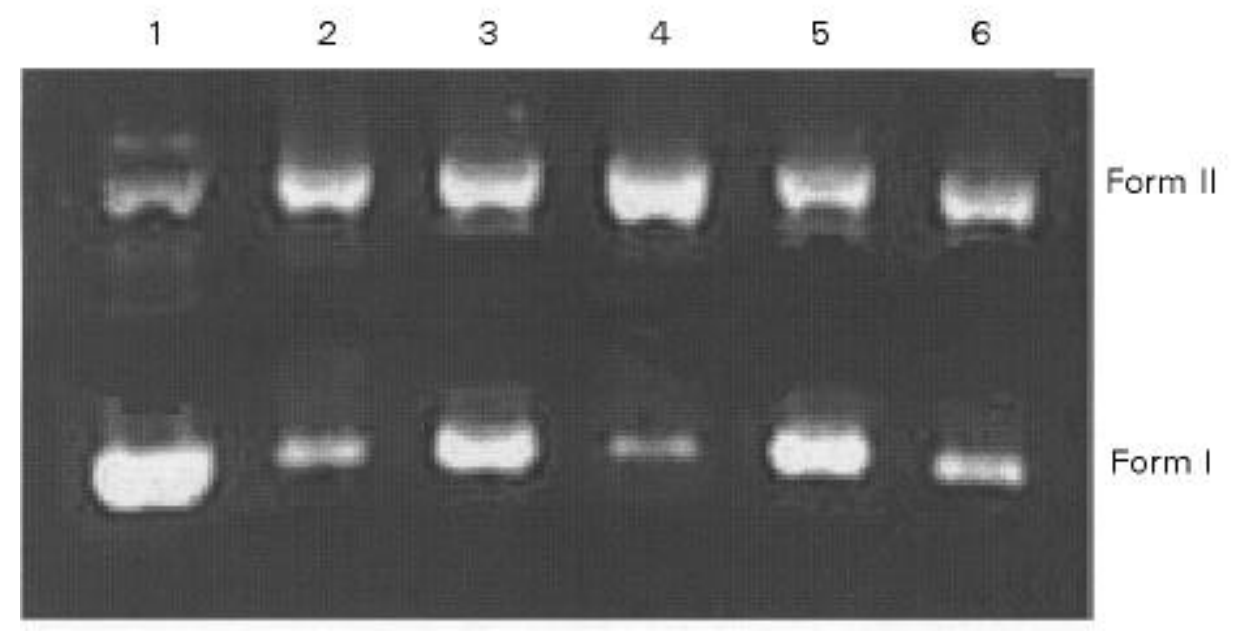

Figure 9. Cleavage of SC pUC19 DNA $(0.5 \mu \mathrm{g})$ by the Schiff base complexes $(30 \mu \mathrm{M})$ in the presence of ascorbic acid $\left(\mathrm{H}_{2} \mathrm{~A}, 100 \mu \mathrm{M}\right)$ in a $50 \mathrm{mM}$ Tris$\mathrm{HCl}+50 \mathrm{mM} \mathrm{NaCl}$ buffer at $37^{\circ} \mathrm{C}$. Lane 1 , DNA control; lane 2 , DNA $+\mathrm{H}_{2} \mathrm{~A}+$ bisphen copper(II) complex; lane 3, DNA + $\mathrm{H}_{2} \mathrm{~A}+$ complex 7 ( $\mathrm{L}=$ phen); lane 4, DNA + $\mathrm{H}_{2} \mathrm{~A}+$ complex $8(\mathrm{~L}=\mathrm{dpq})$; lane 5 , DNA + $\mathrm{H}_{2} \mathrm{~A}+$ complex $6(\mathrm{~L}=\mathrm{bpy})$; lane 6 , DNA $+\mathrm{H}_{2} \mathrm{~A}+$ complex $9(\mathrm{~L}=\mathrm{dppz})$.

efficient binder than phen and dpq. The reason could be the specificity of groove choice for these planar ligands. While phen and dpq may prefer minor groove, dppz may bind through the major groove.

The cleavage of pUC19 DNA by the complexes 6-9 in presence of ascorbic acid $\left(\mathrm{H}_{2} \mathrm{~A}\right)$ is studied. The agarose gel electrophoresis diagram is shown in figure 9. It is apparent from the cleavage pattern that the cleavage efficiency follows the order: $\mathrm{Cu}(\text { phen })_{2}{ }^{2+} \approx$ 
8> 7>9 $>6$. While the bpy and dppz complexes are found to be poor cleavers of DNA, the dpq complex has similar activity as the bis-phen copper complex.

\section{Experimental}

All reagents and chemicals were purchased from commercial sources. Solvents were purified by standard procedures. Dipyridoquinoxaline and dipyridophenazine were prepared by literature methods ${ }^{28,34,35}$. The glycinatosalicylaldimine Schiff base containing precursor complex $\left[\mathrm{Cu}(\mathrm{salgly})\left(\mathrm{H}_{2} \mathrm{O}\right)\right] \cdot 0 \cdot 5 \mathrm{H}_{2} \mathrm{O}$ was prepared by a known procedure $^{36}$. Calf thymus (CT) DNA and supercoiled (SC) pUC19 DNA were purchased from Bangalore Genie (India). Agarose (molecular biology grade) and ethidium bromide (2,7-diamino-10-ethyl-9-phenylphenanthridinium bromide) were from Sigma (USA). Tris-(hydroxymethyl) aminomethane. hydrochloride (Tris-HCl) buffer solutions were prepared using deionised, sonicated triple distilled water.

The CHN analyses were carried out on a Perkin-Elmer 2400 instrument. All the complexes gave satisfactory elemental analysis data. The infrared, electronic and fluorescence spectra were recorded on a Bruker Equinox 55, Hitachi U-3400 and PerkinElmer LS 50B spectrophotometers, respectively. Electrochemical measurments were made at $25^{\circ} \mathrm{C}$ on a EG\&G PAR Model 253 Versa Stat Potentiostat/Galvanostat using a three-electrode setup comprising of a glassy carbon working, platinum wire auxiliary and a saturated calomel reference electrode (SCE). The experimental data were uncorrected for junction potentials.

Complex $\left[\mathrm{Cu}(\mathrm{dpq})_{2}\left(\mathrm{H}_{2} \mathrm{O}\right)\right]\left(\mathrm{ClO}_{4}\right)_{2} \cdot \mathrm{H}_{2} \mathrm{O}$ (1) was prepared in high yield by reacting $1.0 \mathrm{mmol}$ of $\mathrm{Cu}\left(\mathrm{ClO}_{4}\right)_{2} \cdot 6 \mathrm{H}_{2} \mathrm{O}$ with $2.0 \mathrm{mmol}$ of dpq in $15 \mathrm{ml} \mathrm{MeOH}$ under stirring condition for $0.5 \mathrm{~h}$ at $25^{\circ} \mathrm{C}$. The solid thus formed was isolated, washed with cold methanol and dried in vaccuo over $\mathrm{P}_{4} \mathrm{O}_{10}$. The oxalato bridged dicopper(II) complexes $\left[\left\{\mathrm{CuL}\left(\mathrm{H}_{2} \mathrm{O}\right)\right\}_{2}(\boldsymbol{\mu}\right.$-ox $\left.)\right]\left(\mathrm{ClO}_{4}\right)_{2}(\mathbf{2}-\mathbf{5})$ were prepared by following a general procedure in which $1.0 \mathrm{mmol}$ of $\mathrm{Cu}\left(\mathrm{ClO}_{4}\right)_{2} \cdot 6 \mathrm{H}_{2} \mathrm{O}$ was reacted with $1.0 \mathrm{mmol}$ of $\mathrm{L}$ and $0.5 \mathrm{mmol}$ of sodium oxalate in $70 \mathrm{ml}$ aqueous ethanol. The complexes were isolated in $70 \%$ yield as a blue solid after washing the crude solid with ethanol and water followed by drying over $\mathrm{P}_{4} \mathrm{O}_{10}$. Complexes $[\mathrm{Cu}($ salgly $)(\mathrm{L})] \cdot 4 \mathrm{H}_{2} \mathrm{O}(6-9)$ were prepared by reacting an equimolar mixture of $\left[\mathrm{Cu}(\right.$ salgly $\left.)\left(\mathrm{H}_{2} \mathrm{O}\right)\right] \cdot 0 \cdot 5 \mathrm{H}_{2} \mathrm{O}$ and $\mathrm{L}$ in $30 \mathrm{ml}$ aqueous methanol $(1: 5 \mathrm{v} / \mathrm{v})$ under stirring for $1 \mathrm{~h}$ at $25^{\circ} \mathrm{C}$. The complexes were isolated in $\sim 80 \%$ yield as a dark green solid on evaporation of the solvent and finally crystallized from an aqueous methanolic solution of the complex by evaporation at $5^{\circ} \mathrm{C}$. Complexes $\left[\mathrm{Cu}(\mathrm{dpq})_{2}\left(\mathrm{H}_{2} \mathrm{O}\right)\right]\left(\mathrm{ClO}_{4}\right)_{2} \cdot \mathrm{H}_{2} \mathrm{O}$ (1), $\left[\left\{\mathrm{CuL}\left(\mathrm{H}_{2} \mathrm{O}\right)\right\}_{2}(\boldsymbol{\mu}\right.$ ox $\left.)\right]\left(\mathrm{ClO}_{4}\right)_{2} \quad(\mathrm{~L}=\mathrm{bpy}, \mathbf{2} ; \mathrm{dpq}, \mathbf{4})$ and $[\mathrm{Cu}(\mathrm{salgly})(\mathrm{bpy})] .4 \mathrm{H}_{2} \mathrm{O}$ (6) were characterized by single crystal X-ray crystallography. A detailed report on the crystal structures will be published elsewhere.

In the DNA binding studies, the concentration of the CT DNA was determined by recording the absorption intensity at $260 \mathrm{~nm}$ with a molar extinction coefficient value $6600 \mathrm{dm}^{3} \mathrm{~mol}^{-1} \mathrm{~cm}^{-137}$. The experiments were done using $0.1 \mathrm{mM}$ complex concentration in the absence and presence of CT DNA varying from 0 to $250 \mu \mathrm{M}$. In order to compare the relative binding of the complexes to DNA with respect to the bisphen complex of copper(II), ethidium bromide bound CT DNA solution in Tris$\mathrm{HCl} / \mathrm{NaCl}$ buffer $(p \mathrm{H} \mathrm{7.2)}$ was treated with an increasing amount of the complex solution. The fluorescence intensities at $610 \mathrm{~nm}(510 \mathrm{~nm}$ excitation) of the ethidium bromide in the bound form were plotted against the complex concentration. 
The cleavage of DNA was monitored using agarose gel electrophoresis. In a typical experiment, supercoiled pUC19 DNA $(6 \mu \mathrm{L}, \sim 0.5 \mu \mathrm{g})$ in Tris- $\mathrm{HCl}$ buffer $(50 \mathrm{mM})$ with $50 \mathrm{mM} \mathrm{NaCl}(p \mathrm{H} \mathrm{7.2})$ was treated with the metal complex $(30 \mu \mathrm{M})$ and ascorbic acid $\left(\mathrm{H}_{2} \mathrm{~A}, 100 \mu \mathrm{M}\right)$ followed by dilution with the Tris-HCl buffer to a total volume of $20 \mu \mathrm{L}$. The samples were incubated for $1 \mathrm{~h}$ at $37^{\circ} \mathrm{C}$. Loading buffer containing $25 \%$ bromophenol blue, $0.25 \%$ xylenecyanol and $30 \%$ glycerol $(3 \mu \mathrm{l})$ was added and the sample was subjected to electrophoresis using $0.8 \%$ agarose gel containing $1.0 \mu \mathrm{g} / \mathrm{ml}$ ethidium bromide at $40 \mathrm{~V}$ for $3 \mathrm{~h}$ in Tris-borate-EDTA (TBE) buffer. Bands were visualised by UV light and photographed. The cleavage activity was estimated by determining the extent of conversion of SC DNA to NC DNA using the BIORAD gel documentation system. The data were corrected for the low level of the NC present in the original sample and for the low affinity of ethidium bromide binding to SC compared to $\mathrm{NC}$ and linear forms of $\mathrm{DNA}^{38}$.

\section{Conclusions}

Redox active copper(II) complexes having planar N-donor heterocyclic ligands are found to be nuclease active in presence of ascorbic acid. The complexes having 2,2'-bpy ligand are poor binder and cleaver to DNA. The copper(II) complexes having dipyridoquinoxaline ligand are good binders to DNA and in presence of ascorbic acid, they show nuclease activity. The cleavage activity of the copper-dpq complexes are comparable to that of the well explored nucleolytic reagent bis-phen complex of copper(I). The copper(II) complexes having dipyridophenazine (dppz) ligand are found to be poor cleaver to DNA in presence of $\mathrm{H}_{2} \mathrm{~A}$. They, however, show different binding ability to DNA in the copper(II) form. The results are of importance in the development of the chemistry of nuclease active redox based copper complexes.

\section{Acknowledgements}

We thank Prof S Mahadevan and Mr G Neelakanta of the Department of Molecular Reproduction, Development \& Genetics for their help in the DNA cleavage studies and Dr M Nethaji of our department for X-ray studies. We are grateful to the Council of Scientific and Industrial Research (CSIR), New Delhi for financial support and to the Alexander von Humboldt Fondation, for donation of an electrochemical system. PANR and BKS thank the CSIR, New Delhi for scholarships.

\section{References}

1. Sigman D S, Bruice T W, Mazumder A and Sutton C L 1993 Acc. Chem. Res. 2698

2. Sigman D S, Mazumder A and Perrin D M 1993 Chem. Rev. 932295

3. Pogozelski W K and Tullius T D 1998 Chem. Rev. 981089

4. Chin J 1991 Acc. Chem. Res. 24145

5. Burrows C J and Muller J G 1998 Chem. Rev. 981109

6. Meunier B 1992 Chem. Rev. 921411

7. Patriviel G, Bernadou J and Meunier B 1998 Adv. Inorg. Chem. 45251

8. Thorp H H 1995 Adv. Inorg. Chem. 43127

9. Pyle A M and Barton J K 1990 Prog. Inorg. Chem. 38413

10. Sigel A and Sigel H 1996 Probing nucleic acids by metal ion complexes of small molecules (New York: Dekker)

11. Barton J K 1986 Science 233727 
12. Francois J-C, Saison-Behmoaras T and Helene C 1988 Nucleic Acids Res. 1611431

13. Francois J-C, Saison-Behmoaras T, Chassignol M, Thuong N T, Sun J-S and Helene C 1988 Biochemistry 29570

14. Guo Q, Lu M, Seeman N C and Kallenbach N R 1990 Biochemistry 29570

15. Veal J M and Rill R L 1988 Biochemistry 271822

16. Oikawa S and Kawanishi S 1996 Biochemistry 354584

17. Yamamoto K and Kawanishi S 1989 J. Biol. Chem. 264 15435; Yamamoto K and Kawanishi S 1991 J. Biol. Chem. 2661509

18. Kubiak M, Duda A M, Garadu M L and Kozlowski H 1996 J Chem. Soc., Dalton Trans. 1905

19. Kawanishi S, Yamamoto K and Inoue S 1889 Biochem. Pharmacol. 383491

20. Singh U S, Scannell R T, An H, Carter B J and Hecht S M 1995 J. Am. Chem. Soc. 11712691

21. Sigman D S, Graham D R, Aurora D and Stern A M 1979 J. Biol. Chem. 25412269

22. Santra B K, Reddy P A N, Neelakanta G, Mahadevan S, Nethaji M and Chakravarty A R 2002 J. Inorg. Biochem. 89191

23. Waring M J 1965 J. Mol. Biol. 13269

24. Le Pecq J-B and Paoletti C 1967 J. Mol. Biol. 2787

25. Changzheng L, Jigui W, Liufong W, Min R, Naiyong J and Jie G 1999 J. Inorg. Biochem. 73 195; Mahadevan S and Palaniandavar M 1998 Inorg. Chem. 373927

26. Thomas A M, Neelakanta G, Mahadevan S, Nethaji M and Chakravarty A R 2002 Eur. J. Inorg. Chem. (in press)

27. Veal J M, Merchant K and Rill R L 1991 Nucleic Acids Res. 193383

28. Collins J G, Sleeman A D, Aldrich-Wright J R, Greguric I and Hambley T W 1998 Inorg. Chem. 373133

29. Fry J V and Collins J G 1997 Inorg. Chem. 362919

30. Greguric I, Aldrich-Wright J R and Collins J G 1997 J. Am. Chem. Soc. 1193621

31. Erkkila K E, Odom D T and Barton J K 1999 Chem. Rev. 992777

32. Holmlin R E, Stemp E D A and Barton J K 1998 Inorg. Chem. 3729

33. Dupureur C M and Barton J K 1997 Inorg. Chem. 3633

34. Dickenson J E and Summers L A 1970 Aust. J. Chem. 231023

35. Amouyal E, Homsi A, Chambron J-C and Sauvage J-P 1990 J. Chem. Soc., Dalton Trans. 1841

36. Kishita K, Nakahara A and Kubo M 1964 Aust. J. Chem. 17810

37. Reichman M E, Rice S A, Thomas C A and Doty P 1954 J. Am. Chem. Soc. 763047

38. Bernadou J, Patriviel G, Bennis F, Girardet M and Meunier B 1989 Biochemistry 287268 